\title{
SCIENCE-BASED ADVANCES IN THE SOCIAL DOMAIN OF LEARNING DISABILITIES
}

\author{
Tanis Bryan
}

TANIS BRYAN, Ph.D., is co-director, Southwest Institute for Families and Children with Special Needs, Phoenix, Arizona.

\begin{abstract}
"I love to make them laugh because I can see that they are not only enjoying the lessons but also taking a role in them." (Christina Webb, winner of the 2005 Rodel Teacher Initiative, as cited in Young, 2004)
\end{abstract}

Over the past 20 years, teachers have been under continuous pressure to increase students' academic achievement gains. The No Child Left Behind Act of 2001 (NCLB), the latest effort in the 20+-year-old school reform movement, is a federal mandate that demands in part that school districts implement science-based instructional strategies to ensure that children meet the standards set forth in content curricula. Science-based interventions in the social domain are notably absent.

This omission is unfortunate. Children's social status significantly impacts their participation in the reciprocal teaching-learning process. Many horror stories have detailed the adverse outcomes of ignoring the school's social milieu, from the tragedy at Columbine High School to the many students with learning disabilities who spend their school years depressed and lonely (cf., Margalit \& Al-Yagon, 1994). Although schools define their mission and are evaluated based on students' academic achievement, the reality is that the mental and social health of classrooms impacts everyone's learning.

This should not be the case, for multiple reasons. First, a comprehensive systematic body of research, established under the auspices of the Chicago Institute for Children with Learning Disabilities and replicated numerous times, demonstrated that children with learning disabilities are at high risk for experiencing social problems. This research established the need for educators to factor social relationships into curriculum and instruction design. Second, an impressive body of science also has accumulated, demonstrating that effective social interventions combine teaching adap- tive social behaviors with effective teaching strategies. This combination produces greater learning gains than effective teaching strategies alone (cf., Borkowski, 1992; Schunk, 1984). First grade-teacher Christina Webb integrated several of these strategies (e.g., induced positive affect, feedback and contingent praise) into her daily routines. Unfortunately, the newspaper profile fails to mention the science that supports her strategies.

\section{SCOPE OF THE PROBLEM IN LEARNING DISABILITIES}

The research we did at the Chicago Institute for Learning Disabilities produced consistent results detailing the types of social skills problems that students with learning disabilities were likely to experience (cf., Bryan \& Bryan, 1983; Donahue, Pearl, \& Bryan, 1983). Our efforts, replicated by other researchers across the past 30+ years, established time and again that students with learning disabilities are at risk for social problems across age (preschool through adulthood), race, settings (rural-urban), raters (parents, teachers, peers, self), and countries (United States, Canada, Israel, New Zealand, South Africa). Estimates consistently indicate that $38 \%-75 \%$ of the $2,800,000$ students with learning disabilities in the United States have social problems (Baum, Duffelmeyer, \& Greenlan, 2001; Kavale \& Forness, 1995).

Nonetheless, children's social skills and relationships receive a low priority among teachers and school districts. The social skills that teachers rate as essential for school success are compliance behaviors that affect classroom management (Kerr \& Zigmond, 1986; Lane, Pierson, \& Givner, 2004). What is important is that the child follows directions, cooperates with peers, and has self-control; that is, does what the teacher wants when she wants it, without disturbing anyone else. Although teachers may endorse strategies that promote coopera- 
tive learning and motivation, teachers do not use the motivating strategies they endorse. Pressure to increase standardized test scores increases teachers' reluctance to spend time on activities that are not tested by mandated standardized achievement tests.

Furthermore because social problems are not included in the definition of learning disabilities, school districts are not obligated to assess students' social skills, teachers are unlikely to include social problems in referrals, and few teachers have been assigned responsibility for addressing social skill deficits, not even those skills that teachers identify as critical to classroom management (Baum et al., 2001). In spite of this depressing state of affairs, researchers have plowed ahead and built a substantial body of data on skill deficits and interventions in the social domain.

\section{ADVANCES IN SOCIAL SKILLS RESEARCH \\ Studies of Characteristics}

Research that we conducted at the Chicago Institute for Learning Disabilities established that students with learning disabilities are at risk for problems in various aspects of the social domain, including: (a) beliefs and feelings about self (self-concept, attributions, self-worth, loneliness, depression, and affect); (b) social cognitive and linguistic skills (social perception, social cognition, role taking, communicative competence); and (c) interpersonal skills (developing and sustaining social relationships, adaptive behavior, classroom behavior). Recently, researchers have expanded the database to multivariate approaches that examine the relationship between neurological variables and social skills (Spafford \& Grosser, 1993) and the relationship between social skills (peer status) and academic skills (phonemic awareness) (Most, Al-Yagon, Tur-Kaspa, \& Margalit, 2000).

Also significant is the expansion of research to ecocultural models that recognize the role that significant others play in the child's development. Ecocultural research focuses on the interactions between characteristics of the individual, family, school, and community. The ecocultural perspective is reflected in the familycentered research that dominates early childhood special education, research on risk and resilience (Wong, 2003), and studies of the peer group membership of students with learning disabilities (Pearl, 2002; Wiener $\&$ Schneider, 2002).

\section{Studies of Effective Interventions}

Over the years more than 200 social skills interventions have been developed. In fact, there have been so many intervention studies that several narrative and quantitative reviews have analyzed their effectiveness (cf., Forness \& Kavale, 1996; Kavale, Mathur, Forness,
Rutherford, \& Quinn, 1997). Overall, social skills interventions have been found to have limited effectiveness in altering social status (peer acceptance), which has been attributed to methodological limitations (e.g., training behaviors not related to the cause of rejection). But certain types of social interventions, namely those focused on affect and self-perceptions (i.e., attributions and locus of control), have been shown to have consistently positive effects on academic achievement.

Positive affect induction. Research in psychology, medicine, nursing, and education has demonstrated that affect influences learning, social relationships, happiness, health, the immune system, and longevity. Positive, in contrast to negative, affect increases access to information stored in memory, assists in the performance of complex cognitive functions that require flexibility, integration, and utilization of cognitive material, increases positive feelings about the self and goodwill toward others, and even improves conflict resolution (Baron, 1990). Finally, affect is "catchy"; we seek out people who are in good moods and avoid those who are depressed or sad.

We conducted a series of affect studies involving students with and without learning disabilities in kindergarten through high school. The results consistently showed that students in positive affect conditions (i.e., "think about something that makes you happy") performed significantly better on math, reading, and social problem-solving tasks than students in neutral affect conditions (cf., Bryan \& Burstein, 2000; Yasutake, Bryan, \& Dohrn, 1996). Positive affect can be induced in many ways at no cost (music, pep talk, self-induced, compliments), take little time (45 seconds), and enhance the performance of all students, thus meeting the feasibility criteria for teacher adoption into practice (Gersten \& Dimino, 2001).

Attribution retraining. A huge body of data has established that adults' and children's concepts of causality influence motivation, choices, and behavioral responses. Research has also demonstrated that people's beliefs can be "retrained" to alter their concepts of causality with subsequent effects on behavior. Thus, elegant studies have demonstrated that children's beliefs about causality can be retrained and, when combined with effective teaching strategies, children acquire more adaptive beliefs and make greater progress in acquiring math and reading skills than when provided effective instruction-only (Borkowski, 1992; Schunk, 1984). However, when we tried to translate this research into practice using such methods as video description and explanation, modeling, peer tutoring, we were able to influence parents' and peer tutors' beliefs and behaviors, but not teachers' (Yasutake et al., 1996). 


\section{THE FUTURE}

Hopefully, one day American communities (i.e., education policy makers, educators, families) will recognize the science-based justification for attending to children's social status and developing socially healthy classroom environments. Hopefully, one day American communities will advocate for applying science-based social interventions to help all children acquire the personal and interpersonal skills they need to maximize their self-efficacy and academic achievement. Hopefully, researchers will have opportunities to continue advancing our understanding of the multiple factors that influence how children with learning disabilities acquire social competence.

First-grade teacher Christina Webb gets it, and got rewarded for it.

\section{REFERENCES}

Baron, R. A. (1990). Self-presentation in job interviews: When there can be "too much of a good thing." Journal of Applied Social Psychology, 16, 16-28.

Baum, D. D., Duffelmeyer, F., \& Greenlan, M. (2001). Resource teacher perceptions of the prevalence of social dysfunction among students with learning disabilities. Journal of Learning Disabilities, 21, 380-381.

Borkowski, J. G. (1992). Metacognitive theory: A framework for teaching literacy, writing and math skills. Journal of Learning Disabilities, 25, 253-257.

Bryan, J., \& Bryan, T. (1983). The social life of the learning disabled youngster. In J. D. McKinney \& L. Feagans (Eds.), Current topics in learning disabilities (Vol. I). New York: Ablex.

Bryan, T., \& Burstein, K. (2000). Don't worry, be happy: The effect of positive mood on learning. Thalamus, 18(2), 34-42.

Donahue, M., Pearl, R., \& Bryan, T. (1983). Communicative competence in learning disabled children. In I. Bialer \& K. D. Gadow (Eds.), Advances in learning and behavioral disabilities (Vol. II, pp. 49-84). Greenwich, CT: JAI Press.

Forness, S. R., \& Kavale, K. A. (1996). Treating social skill deficits in children with learning disabilities: A meta-analysis of the research. Learning Disability Quarterly, 19, 2-13.

Gersten, R., \& Dimino, J. (2001). The realities of translating research into classroom practice. Learning Disabilities Research \& Practice, 16, 120-130.
Kavale, K. A., \& Forness, S. R. (1995). Social skills deficits and training: A meta-analysis of the research in learning disabilities. In T. E. Scruggs \& M. A. Mastropieri (Eds.), Advances in learning and behavioral disabilities (pp. 119-160). Greenwich, CT: JAI Press.

Kavale, K. A., Mathur, S. R., Forness, S. R., Rutherford, R. B. Jr., \& Quinn, M. M. (1997). Effectiveness of social skills training for students with behavior disorders: A meta-analysis. Advances in Learning and Behavioral Disabilities, 11, 1-26.

Kerr, M. M., \& Zigmond, N. (1986). What do high school teachers want? A study of expectations and standards. Education and Treatment of Children, 9, 239-249.

Lane, K. L., Pierson, M. R., \& Givner, C. C. (2004). Secondary teachers' views on social competence. Journal of Special Education, 38, 174-186.

Margalit, M., \& Al-Yagon, M. (1994). Learning disability subtyping, loneliness, and classroom adjustment. Learning Disability Quarterly, 17, 297-310.

Most, T., Al-Yagon, M., Tur-Kaspa, H., \& Margalit, M. (2000). Phonological awareness, peer nominations, and social competence among preschool children at-risk for developing learning disabilities. International Journal of Disability, Development, and Education, 47(1), 89-105.

Pearl, R. (2002). Students with learning disabilities and their classroom companions. In B.Y.L. Wong \& M. L. Donahue (Eds.), The social dimensions of learning disabilities: Essays in honor of Tanis Bryan (pp. 77-92). Mahwah, NJ: Lawrence Erlbaum.

Schunk, D. H. (1984). Sequential attributional feedback and children's achievement behaviors. Journal of Educational Psychology, 76, 1159-1169.

Spafford, C. S., \& Grosser, G. S. (1993). The social misperception syndrome in children with LD: Social causes versus neurological variables. Journal of Learning Disabilities, 26, 178-189.

Wiener, J., \& Schneider, B. (2002). A multisource exploration of friendship patterns of children with and without LD. Journal of Abnormal Child Psychology, 30, 127-141.

Wong, B.Y.L. (2003). General and specific issues for researchers' consideration in applying the risk and resilience framework to the social domain of LD. Learning Disabilities Research and Practice, 18, 68-76.

Yasutake, D., Bryan, T., \& Dohrn, E. (1996). The effects of combining peer tutoring and attribution training on students' perceived self-competence. Journal of Remedial and Special Education, 17, 83-91.

Young, T. (2004, November 28). A smile, praise work wonders for teacher. The Arizona Republic, p. 8. 